\title{
Cross-reactivity of Vaccine and Fields Strains of Bovine Coronaviruses in Korea
}

\author{
Garam Lee ${ }^{1}$, Jae-Young Song ${ }^{1}$, In-Soo Cho ${ }^{2}$ and Sorah Yoon ${ }^{1 *}$ \\ ${ }^{1}$ Virology Division, ${ }^{2}$ Foreign Animal Disease Division, Department of Veterinary Research, \\ National Veterinary Research \& Quarantine Service, Anyang, Korea
}

\begin{abstract}
Bovine coronavirus $(\mathrm{BCoV})$ causes severe diarrhea in newborn calves, and is associated with winter dysentery in adult cattle and respiratory infections in calves and feedlot cattle. Although the Korean BCoV vaccine strain, BC94, was isolated in 1995, there has still been no report of a molecular characterization of the vaccine strain. To characterize the vaccine strain, relationships between BC94 and field strains were investigated, based on sequence analysis and cross-immunity. We determined the complete sequences of the HE, N, and S genes from BC94 and four NVRQS isolates (SUN5, A3, 0501, 0502). Due to its major role in antigenicity, the spike proteins of the BCoVs were analyzed. BC94 showed distinctive genetic divergence from field isolates collected from 2002 to 2005. BC94, SUN5, and A3 had no virulence-specific sequence and there was a single amino acid change, from asparagine to lysine at residue 175 , in the polymorphic region. Strains 0501 and 0502 had virulence-specific sequences at all seven sites. Although the recently isolated Korean BCoVs and BC94 were genetically different, the cleavage site of spike genes at 763 768 (KRRSRR) and the antigenic domain II of the spike protein, amino acid position 528, were conserved in all NVRQS isolates. The antigenic relatedness of $\mathrm{KCD}$, representative of recent Korean $\mathrm{BCoVs}$, was compared with the Korean vaccine strain BC94. KCD9 showed cross-reactivity against BC94 by virus neutralization (VN) test. These results suggest that BC94 is antigenically closely related to field isolates and is still effective as a vaccine strain.
\end{abstract}

Key Words: Bovine coronavirus; Vaccine strain; Cross-reactivity

\section{INTRODUCTION}

Bovine coronavirus $(\mathrm{BCoV})$ is a member of the family Coronaviridae of the order Nidovirales (1) and causes severe diarrhea in neonatal calves (CD), winter dysentery (WD) in adult cattle, and respiratory disease in feedlot

Received: October 12, 2009/ Revised: February 8, 2010

Accepted: March 10, 2010

Corresponding author: Sorah Yoon. Virology Division, Department of Veterinary Research, National Veterinary Research \& Quarantine Service, 480 Anyang 6-dong, Manan-gu, Anyang-city, Gyeonggi-do 430-824, Korea.

Phone: +82-31-467-1791, Fax: +82-31-467-1797

e-mail: yoonsra@nvrqs.go.kr

${ }^{* *}$ This work is supported by NVRQS (National Veterinary Research Quarantine Service) of Korean Ministry for Food, Agriculture, Forestry and Fisheries. cattle (2 6). BCoV is a $30-\mathrm{kb}$ single-stranded, plus-sense RNA genome virus, consisting of five major structural proteins: nucleocapsid $(\mathrm{N})$ protein, the transmembrane $(\mathrm{M})$ protein, the small envelope (E) protein, the spike (S) protein, and the hemagglutinin-esterase (HE) protein (7). Both $\mathrm{S}$ and $\mathrm{HE}$ glycoproteins are able to induce erythrocyte hemagglutination, by binding to the $N$-acetyl-9-Oacetylneuraminic acid (Neu 5,9 $\mathrm{Ac}_{2}$ )-containing receptor, but $\mathrm{S}$ protein has been proposed to play the major role to attachment of virus to cell surface receptor $(8,9)$.

The coronavirus spike (S) protein, which is cleaved at amino acid positions 768 and 769, to form two subunits, S1 (N-terminus) and S2 (C-terminus), has several important functions, including viral attachment to the host cell, mediation of membrane fusion, and antibody neutralization 
(10 17). Chouljenko reported that the spike gene includes a putative signal peptide (aa 1 17), S1A immunoreactive domain (aa 351 403), S1B immunoreactive domain (aa 517 621), hydrophobic region (aa 955 992), heptad repeat sequence (aa 993 1032), and carboxyl-terminal anchor sequence (aa 1312 1325) (18).

The $\mathrm{HE}$ and $\mathrm{S}$ glycoproteins are more immunogenic than the N protein and M glycoprotein (19). The S2 subunit is conserved, but a single amino acid change $(528 \mathrm{~V})$ in the S1 subunit confers resistance to the viral neutralization (20, 21).

Molecular analyses of American and Canadian isolates have been conducted by comparing their $\mathrm{S}$ and $\mathrm{HE}$ genes (22-27). Korean calf diarrhea (KCD) strains and Korean winter dysentery (KWD) strains were isolated during the period from 2002 to 2004 and comparative studies have been performed based on their $\mathrm{S}$ and $\mathrm{HE}$ gene sequences (28 30).

In the present study, we compared recently isolated Korean $\mathrm{BCoV}$ and the Korean vaccine strain, based on their immunological and genomic properties to determine whether the recently isolated strains should be considered as new vaccine strains. Cross-reactivity was observed between the Korean vaccine strain and presently widespread bovine coronaviruses.

\section{MATERIALS AND METHODS}

\section{Vaccine and field strains}

Field strains of BCoV were isolated in Korea from 1994 to 2005 from fecal samples, prepared as described previously (31). Each sample was inoculated in cultures of human rectal tumor cells (HRT-18) and MDBK cells to isolate the virus. The Korean vaccine strain BC94 was isolated in 1994 by the National Veterinary Research and Quarantine Service (NVRQS).

\section{RNA extraction, cDNA synthesis, and RT-PCR}

Total RNA was extracted from a $200 \mu$ starting volume of supernatant fluids from infected HRT-18 cells using the

Table 1. The oligonucleotide primers of HE, N and S gene. Mebus strain (GenBank accession No. U00735) used for DNA cloning and sequencing

\begin{tabular}{|c|c|c|c|c|}
\hline Gene name & Primer name & Sequence & Location & Reference \\
\hline \multirow[t]{12}{*}{ S } & S1F & 5'-ATGTTTTTGATACTTTTAATTTCC-3' & S gene $1 \sim 920$ & 30 \\
\hline & S1R & 5'-ACACCAGTAGATGGTGCTAT-3' & & \\
\hline & $\mathrm{S} 2 \mathrm{~F}$ & 5'-GGGTTACACCTCTCACTTCT-3' & S gene $782 \sim 1550$ & \\
\hline & $\mathrm{S} 2 \mathrm{R}$ & 5'-GCAGGACAAGTGCCTATACC-3' & & \\
\hline & $\mathrm{S} 3 \mathrm{~F}$ & 5'-CTGTCCGTGTAAATTGGATG-3' & S gene $1459 \sim 2286$ & \\
\hline & S3R & 5'-TGTAGAGTAATCCACACGT-3' & & \\
\hline & S4F & 5'-TTCACGACAGCTGCAACCTA-3' & S gene $2151 \sim 3022$ & \\
\hline & S4R & 5'-CCATGGTAACACCAATCCCA-3' & & \\
\hline & S5F & 5'-CCCTGTATTAGGTTGTTTAG-3' & S gene $2691 \sim 3606$ & \\
\hline & S5R & 5'-ACCACTACCAGTGAACATCC-3' & & \\
\hline & S6F & 5'-GTGCAGAATGCTCCATATGGT-3' & S gene $3439 \sim 4092$ & \\
\hline & S6R & 5'-TTAGTCGTCATGTGATGTTT-3' & & \\
\hline \multirow[t]{2}{*}{$\mathrm{HE}$} & HEF & 5'-GGATCCATGTTTTTGCTTCCT-3' & HE gene $1 \sim 1275$ & \\
\hline & HER & 5'-CTCGAGTTATCGTAGTACGTCGGA-3' & & \\
\hline \multirow[t]{2}{*}{$\mathrm{N}$} & $\mathrm{NF}$ & 5'-GGATCCATGTTTTTGCTTCCT-3' & N gene $1 \sim 1347$ & \\
\hline & NR & 5'-CTCGAGTTATATTTCTGAGTGTCTTCT-3' & & \\
\hline
\end{tabular}


Table 2. The GenBank accession numbers of reference strains of $B C V$ vaccine and field isolates

\begin{tabular}{|c|c|c|c|c|}
\hline Strain & Year & $\mathrm{HE}$ & S & $\mathrm{N}$ \\
\hline $\begin{array}{l}\text { BC94 Korean } \\
\text { vaccine }\end{array}$ & 1994 & EU401979 & EU401989 & EU401985 \\
\hline SUN5 & 1994 & EU401978 & EU401988 & EU401984 \\
\hline A3 & 1994 & EU401977 & EU401987 & EU401983 \\
\hline 0501 & 2005 & EU401975 & EU686689 & EU401980 \\
\hline 0502 & 2005 & EU401976 & EU401986 & EU401981 \\
\hline Mebus & 1972 & U00735 & U00735 & U00735 \\
\hline L9 & 1991 & M76372 & M64667 & \\
\hline $\begin{array}{l}\text { Norden } \\
\text { vaccine }\end{array}$ & 1991 & & M64668 & \\
\hline F15 & 1979 & & D00731 & M36656 \\
\hline LY138 & 1965 & AF058942 & AF058942 & AF058942 \\
\hline ENT & 1998 & AF391542 & AF391542 & AF391542 \\
\hline LSU & 1994 & AF058943 & AF058943 & AF058943 \\
\hline $\mathrm{OK}$ & 1996 & AF058944 & AF058944 & AF058944 \\
\hline KCD1 & 2004 & DQ389642 & DQ389632 & \\
\hline KCD2 & 2004 & DQ389643 & DQ389633 & \\
\hline KCD3 & 2004 & DQ389644 & DQ389634 & \\
\hline KCD4 & 2004 & DQ389645 & DQ389635 & \\
\hline KCD5 & 2004 & DQ389646 & DQ389636 & \\
\hline KCD6 & 2004 & DQ389647 & DQ389637 & \\
\hline KCD7 & 2004 & DQ389648 & DQ389638 & \\
\hline KCD8 & 2004 & DQ389649 & DQ389639 & \\
\hline KCD9 & 2004 & DQ389650 & DQ389640 & \\
\hline KWD1 & 2002 & DQ016118 & AY935637 & \\
\hline KWD2 & 2002 & DQ016119 & AY935638 & \\
\hline KWD3 & 2002 & DQ016120 & AY935639 & \\
\hline KWD4 & 2002 & DQ016121 & AY935640 & \\
\hline KWD5 & 2002 & DQ016122 & AY935641 & \\
\hline KWD6 & 2002 & DQ016123 & AY935642 & \\
\hline KWD7 & 2002 & DQ016124 & AY935643 & \\
\hline KWD8 & 2002 & DQ016125 & AY935644 & \\
\hline KWD9 & 2002 & DQ016126 & AY935645 & \\
\hline KWD10 & 2002 & DQ016127 & AY935646 & \\
\hline KWD11 & 2002 & DQ994162 & DQ389652 & \\
\hline KWD12 & 2002 & DQ994163 & DQ389653 & \\
\hline KWD13 & 2002 & DQ994164 & DQ389654 & \\
\hline
\end{tabular}

Table 2. Continued

\begin{tabular}{lcccc}
\hline \hline Strain & Year & HE & S & N \\
\hline KWD14 & 2002 & DQ994165 & DQ389655 & \\
KWD15 & 2002 & DQ994166 & DQ389656 & \\
KWD16 & 2002 & DQ994167 & DQ389657 & \\
KWD17 & 2002 & DQ994168 & DQ389658 & \\
KWD18 & 2002 & DQ994169 & DQ389659 \\
KWD19 & 2002 & DQ994170 & DQ389660 & \\
\hline
\end{tabular}

Trizol reagent (Gibco-BRL, Life Tech, Grand Island, NY, USA). Total cDNAs were synthesized from $2 \mu \mathrm{g}$ of total RNA using Superscript II RNase $\mathrm{H}^{-}$reverse transcriptase (Gibco-BRL) with an oligo(dT) primer. Each cDNA was amplified by PCR using gene-specific primers (Table 1), designed according to the published sequences of the $\mathrm{S}$, $\mathrm{HE}$, and $\mathrm{N}$ genes of the Mebus strain (GenBank accession No. U00735), described by Park et al (30).

\section{DNA sequence analysis and data analysis}

RT-PCR products were purified using a Geneclean Turbo kit (Bio 101, Inc., La Jolla, CA, USA) according to the manufacturer's instructions. DNA sequencing was performed using an automated DNA sequencer (ABI PRISM 3730xl; Applied Biosystems Inc., Foster City, CA, USA). Amino acid sequences were deduced using the DNAStar EditSeq software. Nucleotide and amino acid sequence alignments and phylogenic tree construction were performed using Clustal W in the DNAStar MegAlign software.

\section{Virus neutralization (VN) test for cross-reactivity}

Guinea pigs were inoculated with $\mathrm{BcoV}$ isolate KCD9 and BC94 to produce antisera. Serial two-fold dilutions of serum in $\alpha$-MEM were mixed with the same volume (100 $\mu \mathrm{l})$ of KCD9 and BC94 suspensions containing 200 $\mathrm{TCID}_{50} / 100 \mu \mathrm{l}$ and incubated at $37^{\circ} \mathrm{C}$ for $1 \mathrm{~h}$. HRT-18 cell monolayers grown in 96-well microplates were washed three times with $\alpha$-MEM and then inoculated with $100 \mu \mathrm{l}$ of each virus-serum mixture. Serum samples were tested in triplicate wells. The cells were fixed with $80 \%$ acetone 5 days after inoculation and assessed by a direct immunofluorescence assay (32). Virus-neutralizing antibody titers 
are expressed as the reciprocals of the highest serum titration of each virus was performed. dilution that completely neutralized virus replication. Back

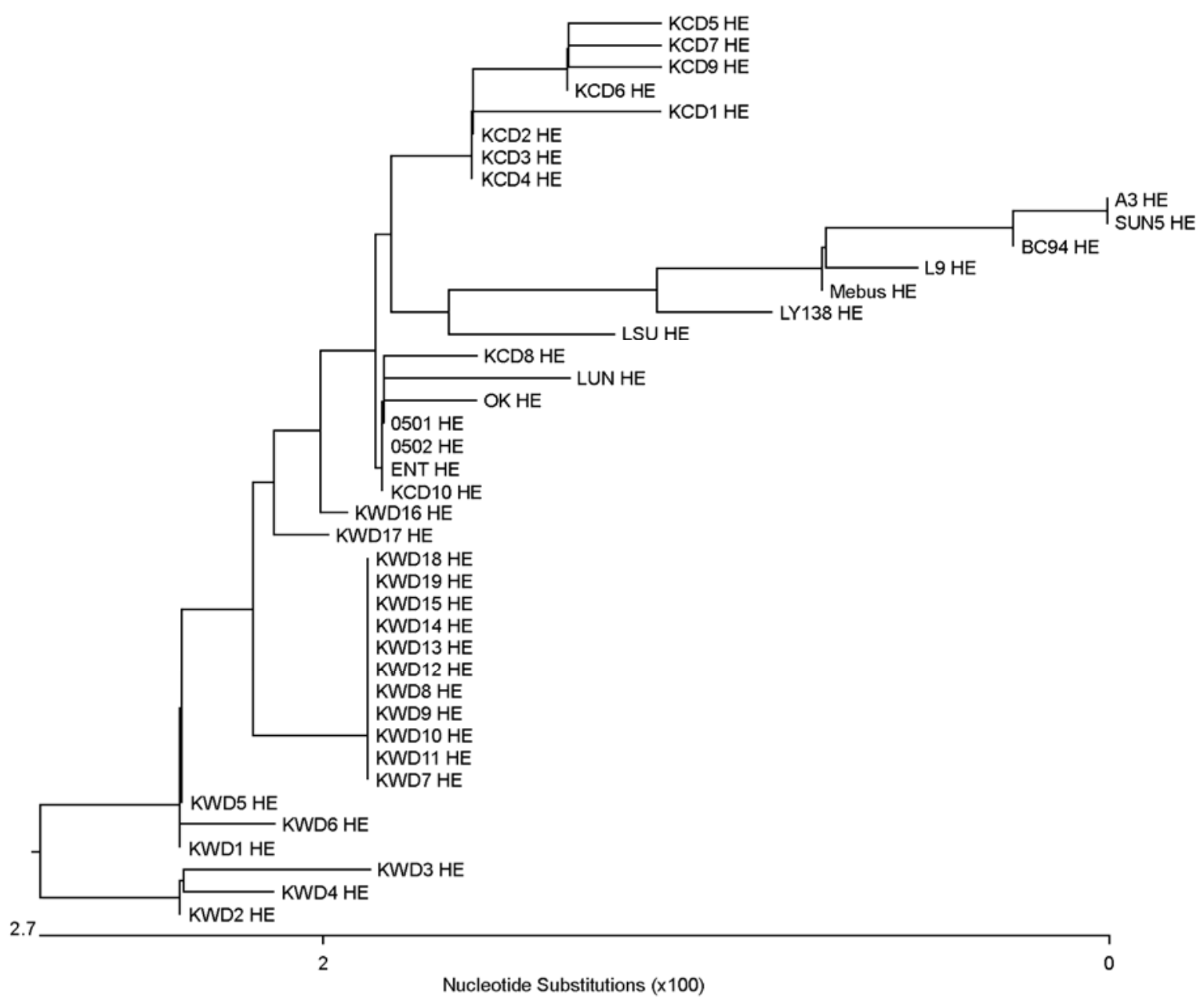

Figure 1. Phylogenic tree of BCV HE. Mebus, L9, F15, LY-138, ENT, vaccine strain M64668, Korean vaccine BC94, SUN5, 0501, 0502, KWDs, and KCDs were analyzed by using Clustal W multiple alignment method of MegAlign program in DNAstar.

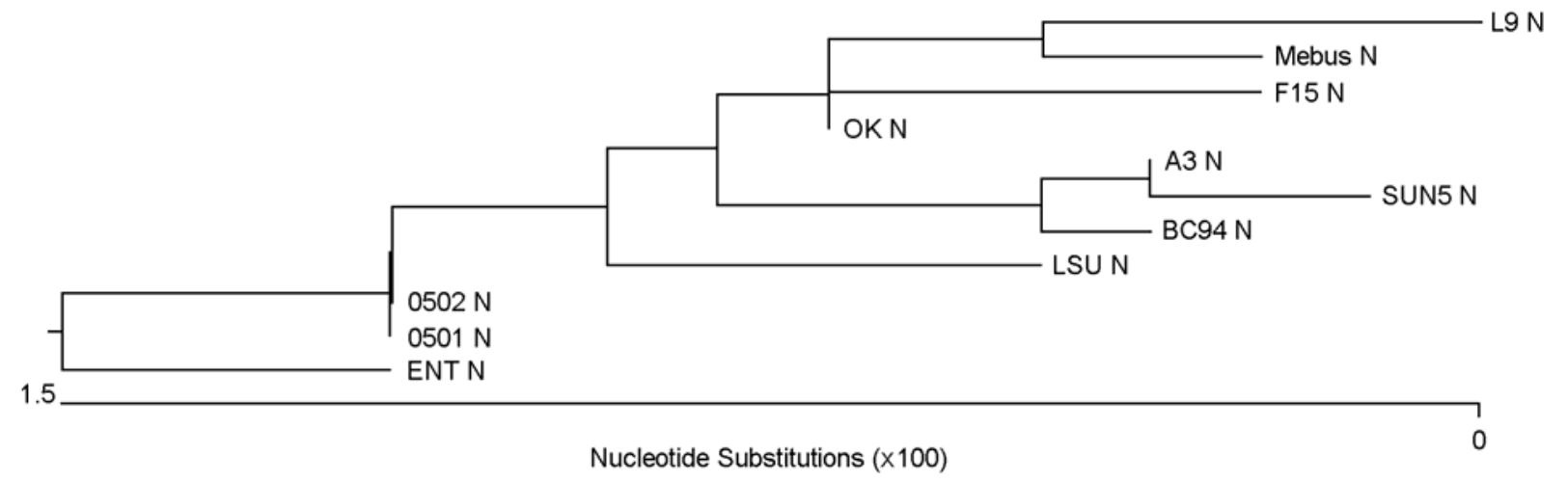

Figure 2. Phylogenic tree of BCV N. Mebus, L9, F15, LY-138, ENT, vaccine strain M64668, Korean vaccine BC94, SUN5, 0501 and 0502 were analyzed by using Clustal W multiple alignment method of MegAlign program in DNAstar. 


\section{RESULTS}

\section{Molecular analysis of HE gene}

The HE genes of BC94 (vaccine strain) and four NVRQS strains (SUN5, A3, 0501, and 0502) each contained an ORF of 1275 nucleotides encoding a predicted product
425 aa residues in length (Table 2). Pair-wise comparisons showed nucleotide and amino acid sequence identities between $\mathrm{BCoV}$ isolates ranging from $97.9 \%$ to $99.8 \%$ and from $98.1 \%$ to $100 \%$, respectively. Sequence alignment was used to create a phylogenetic tree (Fig. 1). Compared with $\mathrm{BC} 94$, we identified six amino acid substitutions in the HE genes of Korean field strains (0501, 0502, KCDs,

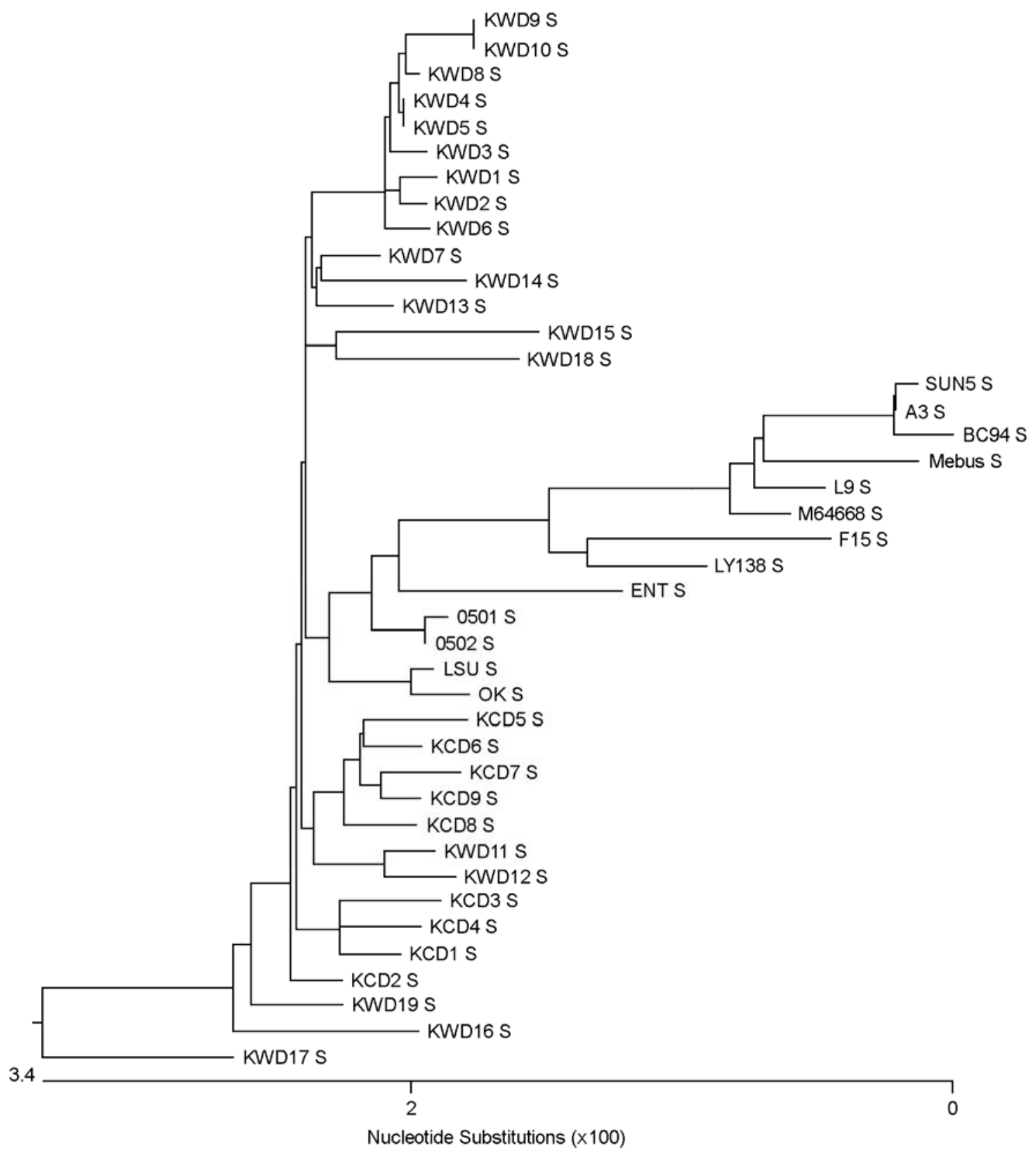

Figure 3. Phylogenic tree of spike proteins of Mebus, L9, F15, LY-138, ENT, vaccine strain M64668, Korean vaccine BC94, SUN5, 0501, 0502, KWDs, and KCDs were made using Clustal W multiple alignment method of MegAlign program in DNAstar. 


\begin{tabular}{|c|c|c|c|c|c|c|c|c|c|c|c|c|c|c|c|c|c|c|c|c|c|c|c|c|c|c|c|}
\hline & 11 & 33 & 40 & 88 & & & & & & & & & & & & & & 499 & & & 563 & 578 & 769 & 965 & 1026 & 1030 & \\
\hline Mebus & $M$ & A & I & $\mathbf{R}$ & I & K & L & N & H & $\mathbf{H}$ & $\mathbf{N}$ & R & L & $S$ & M & 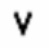 & $\mathbf{H}$ & N & $\mathbf{P}$ & S & $\mathrm{S}$ & $\mathrm{T}$ & A & V & D & E & H \\
\hline L9 & $M$ & $A$ & $\mathbf{T}$ & R & I & $K$ & L & N & H & H & N & R & L & N & M & V & $\mathbf{H}$ & N & P & $\mathrm{S}$ & $\mathrm{S}$ & $\mathrm{T}$ & A & $v$ & D & E & H \\
\hline M64668 & M & A & $T$ & $\mathbf{R}$ & I & $K$ & L & N & H & H & $\mathbf{N}$ & $\mathbf{Q}$ & L & $Y$ & M & V & $\mathrm{H}$ & N & $\mathbf{P}$ & $\mathrm{S}$ & S & $\mathrm{T}$ & A & $v$ & D & E & H \\
\hline F15 & M & v & $\mathbf{T}$ & $T$ & 1 & $\mathrm{H}$ & L & N & $\mathbf{N}$ & H & $\mathbf{N}$ & R & M & N & M & V & D & $\mathrm{H}$ & $\mathbf{P}$ & $\mathrm{s}$ & $\mathrm{S}$ & $T$ & A & E & D & E & $\mathbf{P}$ \\
\hline LY138 & M & $v$ & $\mathbf{T}$ & $\mathbf{T}$ & I & N & L & N & H & H & N & R & M & N & $\mathrm{M}$ & V & D & $\mathrm{S}$ & $\mathrm{S}$ & S & $S$ & $\mathbf{T}$ & A & E & D & E & $\mathbf{P}$ \\
\hline ENT & $\mathbf{T}$ & $v$ & $\mathbf{T}$ & $\mathbf{T}$ & $\mathbf{T}$ & D & L & H & N & N & N & $\mathbf{Q}$ & M & N & L & A & D & $\mathrm{H}$ & $\mathbf{P}$ & S & A & $\mathrm{T}$ & S & E & G & E & $\mathbf{P}$ \\
\hline ISU & $\mathbf{T}$ & V & $\mathbf{T}$ & $T$ & $T$ & D & L & N & $\mathbf{N}$ & N & $\mathbf{N}$ & $\mathbf{Q}$ & M & N & L & A & D & s & S & $T$ & A & $\mathrm{S}$ & S & E & G & E & $\mathbf{P}$ \\
\hline OK & $T$ & v & $\mathbf{T}$ & $T$ & $T$ & D & L & N & $\mathrm{N}$ & N & N & $\mathbf{Q}$ & M & $\mathbf{N}$ & M & A & D & S & $S$ & $T$ & A & $\mathrm{s}$ & S & E & G & E & P \\
\hline BC94 & M & A & 1 & R & 1 & $K$ & L & N & H & H & K & R & L & $\mathrm{S}$ & M & V & $\mathrm{H}$ & N & P & $\mathrm{S}$ & $\mathrm{S}$ & $\mathrm{T}$ & A & $V$ & D & E & H \\
\hline SUN5 & $M$ & A & 1 & $\mathbf{R}$ & I & $K$ & L & N & H & H & K & R & L & S & M & $V$ & H & N & $\mathbf{P}$ & S & $\mathrm{S}$ & $\mathrm{T}$ & A & $v$ & D & E & H \\
\hline A3 & M & A & 1 & $\mathbf{R}$ & I & $K$ & L & $\mathrm{H}$ & H & H & K & R & L & $\mathrm{S}$ & $M$ & V & $\mathrm{H}$ & N & $\mathbf{P}$ & $\mathrm{S}$ & $\mathrm{S}$ & $\mathbf{T}$ & A & $v$ & D & E & H \\
\hline 501 & M & v & $\mathbf{T}$ & $\mathbf{T}$ & $\mathbf{T}$ & D & $F$ & S & N & N & N & $\mathbf{Q}$ & M & N & $\mathrm{L}$ & A & D & N & $\mathbf{P}$ & $\mathrm{S}$ & $\mathrm{S}$ & $\mathbf{T}$ & S & E & G & D & $\mathbf{P}$ \\
\hline 502 & M & v & $\mathbf{T}$ & $\mathbf{T}$ & $T$ & D & $F$ & $\mathrm{~s}$ & N & N & N & $\mathbf{Q}$ & M & N & L & A & D & $\mathrm{H}$ & $\mathbf{P}$ & $\mathrm{S}$ & S & $\mathbf{T}$ & S & E & G & D & $\mathbf{P}$ \\
\hline KCD1 & M & v & $\mathbf{T}$ & $\mathrm{T}$ & $T$ & D & $F$ & $\mathrm{~S}$ & $\mathbf{N}$ & H & N & $\mathbf{Q}$ & M & N & L & A & D & $\mathrm{s}$ & S & $\mathbf{T}$ & A & $\mathrm{S}$ & S & E & G & D & $\mathbf{P}$ \\
\hline $\mathrm{KCD} 2$ & M & $v$ & $\mathbf{T}$ & $\mathbf{T}$ & $T$ & D & $F$ & $\mathrm{~s}$ & N & N & N & $\mathbf{Q}$ & M & N & L & A & D & $T$ & S & $T$ & A & $\mathrm{S}$ & S & E & G & D & $\mathbf{P}$ \\
\hline $\mathrm{KCD} 3$ & M & v & $\mathbf{T}$ & $\mathrm{T}$ & $T$ & D & $F$ & S & N & N & N & $\mathbf{Q}$ & M & N & L & A & D & S & S & $T$ & A & $\mathrm{S}$ & S & E & G & D & $\mathbf{P}$ \\
\hline KCD4 & M & $v$ & $\mathbf{T}$ & R & $\mathbf{T}$ & D & $F$ & $\mathrm{~s}$ & N & N & N & $\mathbf{Q}$ & M & N & L & A & D & $\mathrm{S}$ & $\mathrm{S}$ & $\mathbf{T}$ & A & $\mathrm{S}$ & S & E & G & D & P \\
\hline KCD5 & M & $v$ & $\mathbf{T}$ & $\mathbf{T}$ & $\mathbf{T}$ & G & $F$ & $\mathrm{~s}$ & N & N & N & $\mathbf{Q}$ & M & N & L & V & D & S & $\mathrm{S}$ & $\mathbf{T}$ & A & $\mathrm{S}$ & $\mathrm{S}$ & E & G & D & H \\
\hline KCD6 & $\mathbf{T}$ & $v$ & $\mathbf{T}$ & $\mathbf{T}$ & $\mathbf{T}$ & G & $F$ & $\mathrm{~s}$ & N & N & N & $\mathbf{Q}$ & M & N & L & A & D & $\mathrm{S}$ & $\mathrm{S}$ & $T$ & A & $\mathrm{S}$ & $\mathrm{S}$ & E & G & D & $\mathbf{P}$ \\
\hline $\mathrm{KCD} 7$ & M & V & $\mathbf{T}$ & $\mathrm{T}$ & $\mathbf{T}$ & G & $F$ & $\mathrm{~s}$ & N & N & N & $\mathbf{Q}$ & M & N & L & A & D & $\mathrm{S}$ & $\mathrm{s}$ & $T$ & A & $\mathrm{S}$ & $\mathrm{S}$ & E & G & D & P \\
\hline KCD8 & M & v & $\mathbf{T}$ & $\mathrm{T}$ & $\mathbf{T}$ & G & $F$ & S & N & N & N & $\mathbf{Q}$ & M & N & L & A & D & $\mathrm{S}$ & S & $\mathbf{T}$ & A & $\mathrm{S}$ & $S$ & E & G & D & P \\
\hline KCD9 & M & v & $\mathbf{T}$ & $\mathrm{T}$ & $\mathbf{T}$ & G & $F$ & S & N & N & N & $\mathbf{Q}$ & M & N & L & A & D & $\mathrm{S}$ & S & $\mathbf{T}$ & A & $\mathrm{S}$ & $S$ & E & G & D & $\mathbf{P}$ \\
\hline KWD1 & $\mathbf{T}$ & $v$ & $\mathbf{T}$ & $\mathrm{T}$ & $\mathbf{T}$ & N & $F$ & $\mathrm{~S}$ & N & N & N & R & M & N & L & A & D & $\mathrm{S}$ & $\mathrm{S}$ & $T$ & A & $\mathrm{S}$ & $S$ & E & G & E & $\mathbf{P}$ \\
\hline KWD2 & $\mathbf{T}$ & $v$ & $\mathbf{T}$ & $\mathbf{T}$ & $T$ & N & $F$ & $\mathrm{~S}$ & N & N & N & R & M & N & L & A & D & $\mathrm{S}$ & $\mathrm{S}$ & $\mathbf{T}$ & A & $\mathrm{S}$ & $S$ & E & G & E & $\mathbf{P}$ \\
\hline KWD3 & M & V & $\mathbf{T}$ & $\mathbf{T}$ & $T$ & N & $F$ & $\mathrm{~S}$ & N & N & N & R & M & N & L & A & D & $\mathrm{H}$ & S & $\mathbf{T}$ & A & $\mathrm{S}$ & S & E & G & E & $\mathbf{P}$ \\
\hline KWD4 & M & $v$ & $\mathbf{T}$ & $\mathbf{T}$ & $\mathbf{T}$ & N & $F$ & $\mathrm{~s}$ & N & N & N & R & M & N & L & A & D & $\mathrm{S}$ & S & $\mathbf{T}$ & A & $\mathrm{S}$ & S & E & G & E & $\mathbf{P}$ \\
\hline KWD5 & $M$ & v & $T$ & $\mathbf{T}$ & $T$ & N & $F$ & $\mathrm{~S}$ & N & H & N & R & M & N & L & A & D & $\mathrm{S}$ & $\mathrm{S}$ & $\mathbf{T}$ & A & $\mathrm{s}$ & S & E & G & E & $\mathbf{P}$ \\
\hline KWD6 & M & v & $T$ & $\mathbf{T}$ & $T$ & H & $F$ & $\mathrm{~s}$ & N & N & N & R & M & N & L & A & D & $S$ & $\mathrm{~S}$ & $T$ & A & $\mathrm{s}$ & S & E & G & E & $\mathbf{P}$ \\
\hline KWD7 & M & v & $\mathbf{T}$ & $\mathbf{T}$ & $T$ & D & $F$ & $\mathrm{~S}$ & N & N & N & R & M & N & $\mathrm{L}$ & A & D & $\mathrm{S}$ & S & $T$ & A & $\mathrm{S}$ & S & E & G & D & $\mathbf{P}$ \\
\hline KWD8 & M & $v$ & $\mathbf{T}$ & $T$ & $T$ & N & $F$ & $\mathrm{~S}$ & N & N & $\mathbf{N}$ & R & M & N & $\mathrm{L}$ & A & D & $\mathrm{H}$ & S & $\mathbf{T}$ & A & $\mathrm{S}$ & $\mathrm{S}$ & E & G & E & $\mathbf{P}$ \\
\hline KWD9 & M & v & $T$ & $\mathbf{T}$ & $T$ & N & $F$ & $\mathrm{~s}$ & N & N & N & R & M & N & L & A & D & $K$ & $\mathbf{P}$ & $T$ & A & $\mathrm{s}$ & $\mathrm{S}$ & $\mathbf{Q}$ & G & E & $\mathbf{P}$ \\
\hline KWD10 & M & $v$ & $T$ & $T$ & $\mathbf{T}$ & N & $F$ & S & N & N & $\mathbf{N}$ & R & M & N & L & A & D & $K$ & $\mathbf{P}$ & $\mathbf{T}$ & A & S & S & $Q$ & G & E & $\mathbf{P}$ \\
\hline KWD11 & M & $v$ & $\mathbf{T}$ & $\mathbf{T}$ & $\mathbf{T}$ & D & $F$ & $\mathrm{~S}$ & N & N & N & $\mathbf{Q}$ & M & N & L & A & D & $\mathrm{S}$ & $S$ & $\mathbf{T}$ & A & $\mathrm{S}$ & S & E & G & D & $\mathbf{P}$ \\
\hline KWD12 & M & $v$ & $T$ & $\mathbf{T}$ & $\mathbf{T}$ & D & $F$ & S & N & N & N & $\mathbf{Q}$ & M & N & L & A & D & $\mathrm{S}$ & P & $\mathbf{T}$ & A & $\mathrm{S}$ & S & E & G & D & $\mathbf{P}$ \\
\hline KWD13 & M & $v$ & $T$ & $\mathbf{T}$ & $\mathbf{T}$ & D & $F$ & S & N & N & N & R & M & N & L & A & D & $\mathrm{T}$ & $\mathrm{S}$ & $\mathbf{T}$ & A & $\mathrm{s}$ & S & E & G & D & $\mathbf{P}$ \\
\hline KWD14 & M & V & $\mathbf{T}$ & $\mathbf{T}$ & $T$ & D & $F$ & $\mathrm{~S}$ & N & N & N & R & M & N & L & A & D & $\mathrm{S}$ & $\mathrm{S}$ & $\mathbf{T}$ & A & $\mathrm{s}$ & S & E & G & D & $\mathbf{P}$ \\
\hline KWD15 & M & v & $T$ & $\mathbf{T}$ & $T$ & D & $F$ & $\mathrm{~S}$ & N & N & N & R & M & N & L & A & D & $\mathrm{S}$ & $\mathbf{P}$ & $\mathrm{T}$ & A & $\mathrm{S}$ & S & E & G & E & $\mathbf{P}$ \\
\hline KWD16 & M & v & $T$ & $T$ & $T$ & D & $F$ & S & N & N & $\mathbf{N}$ & $\mathbf{Q}$ & M & N & L & A & D & $\mathrm{S}$ & P & $\mathrm{T}$ & A & $\mathrm{S}$ & S & E & G & D & $\mathbf{P}$ \\
\hline KWD17 & $M$ & $v$ & $T$ & $\mathrm{~T}$ & $T$ & D & $F$ & $S$ & N & N & N & $\mathbf{Q}$ & M & N & L & A & D & $\mathrm{s}$ & s & $T$ & A & s & s & E & G & D & $\mathbf{P}$ \\
\hline KWD18 & M & v & $\mathrm{T}$ & $\mathbf{T}$ & $T$ & D & $F$ & $\mathrm{~S}$ & N & N & N & $\mathbf{Q}$ & M & N & L & A & D & $\mathrm{S}$ & P & $T$ & A & $S$ & S & E & G & D & $P$ \\
\hline KWD19 & $\mathrm{T}$ & V & $\mathbf{T}$ & $\mathbf{T}$ & $T$ & D & $F$ & $\mathrm{~S}$ & N & N & $\mathbf{N}$ & $\mathbf{Q}$ & M & N & L & A & D & $\mathrm{S}$ & S & $\mathbf{T}$ & A & S & S & E & G & D & P \\
\hline
\end{tabular}

Figure 4. Comparison of the deduced amino acid sequences of hypervariable region in spike proteins. Light-gray boxes contain respiratory bovine coronavirus (RBCV)-specific; dark-gray boxes contain virulent-specific and black boxes show significant sequence compared to recent Korean wide-spread BCoVs. 
KWDs) at L5P, C16S, D66G, H124Q, S367P, and L392I.

\section{Molecular analysis of $\mathrm{N}$ gene}

The N genes of the BC94 strain and four NVRQS strains each contained an ORF of 1347 nucleotides, encoding a predicted product of 449 aa residues. Pair-wise comparisons showed nucleotide and amino acid sequence identities between $\mathrm{BCV}$ isolates ranging from $98.0 \%$ to $99.9 \%$ and from $98.2 \%$ to $99.8 \%$, respectively. Compared with BC94, we identified three amino acid changes (D77E, P162L, $\mathrm{S} 423 \mathrm{I})$ in the $\mathrm{N}$ gene. The phylogenic relationships between the $\mathrm{N}$ genes are shown in Figure 2.

\section{Molecular analysis of S gene}

The S genes of BC94 and four NVRQS strains each contained an ORF of 4092 nucleotides encoding a predicted product of 1346 aa residues. Sequence alignment analysis revealed nucleotide and amino acid sequence identities between $\mathrm{BCV}$ isolates ranging from $97.9 \%$ to $99.9 \%$ and from $97.9 \%$ to $100 \%$, respectively. The phylogenetic relationships between $\mathrm{S}$ genes are shown in Figure 3. In total, 21 aa changes were detected in the S1 subunit (aa 1 768). Fifteen amino acid changes were detected in polymorphic regions in the $\mathrm{N}$-terminal region of the $\mathrm{S} 1$ subunit (aa 1 330) (Fig. 4). The amino acid sequences of SUN5 and A3 strains were $100 \%$ identical to those of the BC94 strain. In the cases of 0501 and 0502, amino acids at positions 499, 501, 510, 543, and 578 were identical, but those at A33V, I40T, R88T, I100T, K115D, L147F, N149S, H169N, H173N, K175N, R179Q, L248M, S252N, M256L, V465A, and H478D were changed, compared with BC94. The amino acid sequences of 0501 and 0502 were similar to those of recent Korean isolates, KCDs and KWDs.

\section{Cross reactivity of Korean vaccine strain and KCD9 strain}

Postinoculation sera of guinea pigs inoculated with KCD9, the representative of recent Korean $\mathrm{BCoVs}$, were tested to determine cross-reactivity to $\mathrm{BC} 94$ by a one-way virus neutralization (VN) test. The $\mathrm{VN}$ antibody titers against both KDC9 and the vaccine strain were determined in sera
Table 3. Cross-reactivity of KCD9 and Korean vaccine strain determined by $\mathrm{VN}$ tests

\begin{tabular}{lcc}
\hline \hline \multirow{2}{*}{ BCV strain } & \multicolumn{2}{c}{ VN antibody titers $(\log 2)$} \\
\cline { 2 - 3 } & KCD9 & Korean strain \\
\hline KCD9 & $6.00 \pm 1.15$ & $6.67 \pm 0.52$ \\
Korean vaccine & $5.75 \pm 0.96$ & $6.17 \pm 0.98$ \\
\hline
\end{tabular}

of all guinea pigs inoculated with KCD9 at postinoculation day 21 (PID21). The VN antibody titers were expressed as $\log 2$ values and did not differ significantly between the homologous and heterologous coronaviruses (Table 3), suggesting that KCD9 had cross-activity to BC94.

\section{DISCUSSION}

BC94 has been used as a vaccine strain in calves in Korea since it was first isolated in 1994 without genetic characterization. In this study, $\mathrm{HE}, \mathrm{S}$, and $\mathrm{N}$ genes were sequenced to investigate the molecular features of BC94, and the genes were compared between vaccine and field strains.

Amino acid substitutions in the putative receptor-binding domain in the $\mathrm{N}$-terminal region of the $\mathrm{S}$ gene can alter the tropism of the coronavirus (33). There were seven virulencespecific and thirteen respiratory $\mathrm{BCoV}(\mathrm{RBCV})$-specific amino acid sites in the $\mathrm{S}$ gene (18).

In the present study, SUN5, A3, and BC94 had no virulence-specific sequence and one amino acid change, from asparagine to lysine at amino acid position 175 in the polymorphic region of the S gene, compared with Mebus. Strains 0501 and 0502 had virulence-specific sequences at all seven sites. The cleavage site of the spike genes, at 763 768 (KRRSRR), was conserved in all NVRQS isolates. Although the recently isolated virus and Korean vaccine strain were genetically different, the antigenic domain II of the spike protein at 528 amino acid position was not changed.

Amino acid changes in the hypervariable sites in strains and emergent years suggested a correlation. $\mathrm{BCoV}$ isolates during the period from 2002 to 2005 were changed at positions $88,147,149,169,256$, and 1030. BC94 and four 
NVRQS isolates had asparagine, proline, serine, serine, and threonine at aa positions 499, 501, 510, 543, and 578, respectively, as in Mebus and the reference vaccine strain (M64668), whereas KWDs, and KCDs had serine, serine, threonine, arginine, and serine, respectively, at these sites (Fig. 4).

Recent Korean isolates collected between 2002 and 2005 showed distinct genetic divergence from Korean isolates collected in 1994, including the vaccine strain.

Analysis of HE and S genes of KCDs and KWDs, which were isolated in 2002 and 2004, respectively, divided HE into four groups and the $\mathrm{S}$ protein into three groups (34). BC94, SUN5, and A3 strains were clustered with LY-138, LSU, Mebus, and L9, as group II, according to the HE genes. Strains 0501 and 0502 were clustered with OK, LUN, ENT, KCD8, and KCD10, as group III, according to the HE genes. BC94, SUN5, and A3 strains were clustered with F15, LSU, Mebus, and L9, as group III, according to the S genes. Strains 0501 and 0502 were clustered with $\mathrm{OK}$, LY138, KCDs, and KWDs, as group I, according to the S genes.

To understand the immunoserological relationships between BC94 and field strains, a cross-reactivity assay was performed. KCD9 was chosen because it is a representative strain with the most common sequence among the field isolates, based on the results of sequence analysis.

The VN antibody titers of KCD9-inoculated antisera against homologous KCD9 and heterologous BC94 were not significantly different. These results indicated that BC94 is antigenically closely related to KCD9 and is still considered as an effective vaccine strain. Further studies are required to investigate cross-protection in calves.

\section{Acknowledgement}

KCD9 virus was kindly provided by Dr. Cho KO (Chonnam Nationl University). We thank Ms. Lee Su-Yeon for her technical assistance.

\section{REFERENCES}

1) Cavanagh D. Nidovirales: a new order comprising
Coronaviridae and Arteriviridae. Arch Virol 1997;142: 629-33.

2) Cho KO, Halbur PG, Bruna JD, Sorden SD, Yoon KJ, Janke BH, Chang KO, Saif LJ. Detection and isolation of coronavirus from feces of three herds of feedlot cattle during outbreaks of winter dysentery-like disease. J Am Vet Med Assoc 2000;217:1191-4.

3) Clark MA. Bovine coronavirus. Br Vet J 1993;149:51 $-70$.

4) Lathrop SL, Wittum TE, Brock KV, Loerch SC, Perino LJ, Bingham HR, McCollum FT, Saif LJ. Association between infection of the respiratory tract attributable to bovine coronavirus and health and growth performance of cattle in feedlots. Am J Vet Res 2000;61:1062-6.

5) Saif LJ, Brock KV, Redman DR, Kohler EM. Winter dysentery in dairy herds: electron microscopic and serological evidence for an association with coronavirus infection. Vet Rec 1991;128:447-9.

6) Storz J, Purdy CW, Lin X, Burrell M, Truax RE, Briggs RE, Frank GH, Loan RW. Isolation of respiratory bovine coronavirus, other cytocidal viruses, and Pasteurella spp from cattle involved in two natural outbreaks of shipping fever. J Am Vet Med Assoc 2000; 216:1599-604.

7) Lai MM, Cavanagh D. The molecular biology of coronaviruses. Adv Virus Res 1997;48:1-100.

8) Schultze B, Gross HJ, Brossmer R, Herrler G. The S protein of bovine coronavirus is a hemagglutinin recognizing 9-O-acetylated sialic acid as a receptor determinant. J Virol 1991;65:6232-7.

9) Schultze B, Wahn K, Klenk HD, Herrler G. Isolated HE-protein from hemagglutinating encephalomyelitis virus and bovine coronavirus has receptor-destroying and receptor-binding activity. Virology 1991;180:221-8.

10) Cavanagh D, Davis PJ. Coronavirus IBV: removal of spike glycopolypeptide S1 by urea abolishes infectivity and haemagglutination but not attachment to cells. J Gen Virol 1986;67:1443-8.

11) Saeki K, Ohtsuka N, Taguchi F. Identification of spike protein residues of murine coronavirus responsible for receptor-binding activity by use of soluble receptorresistant mutants. J Virol 1997;71:9024-31.

12) Yoo D, Parker MD, Babiuk LA. Analysis of the S spike (peplomer) glycoprotein of bovine coronavirus 
synthesized in insect cells. Virology 1990;179:121-8.

13) Storz J, Rott R, Kaluza G. Enhancement of plaque formation and cell fusion of an enteropathogenic coronavirus by trypsin treatment. Infect Immun 1981; 31:1214-22.

14) Sturman LS, Ricard CS, Holmes KV. Proteolytic cleavage of the $\mathrm{E} 2$ glycoprotein of murine coronavirus: activation of cell-fusing activity of virions by trypsin and separation of two different $90 \mathrm{~K}$ cleavage fragments. J Virol 1985;56:904-11.

15) Deregt D, Babiuk LA. Monoclonal antibodies to bovine coronavirus: characteristics and topographical mapping of neutralizing epitopes on the E2 and E3 glycoproteins. Virology 1987;161:410-20.

16) Grosse B, Siddell SG. Single amino acid changes in the S2 subunit of the MHV surface glycoprotein confer resistance to neutralization by $\mathrm{S} 1$ subunit-specific monoclonal antibody. Virology 1994;202:814-24.

17) Luytjes W, Geerts D, Posthumus W, Meloen R, Spaan W. Amino acid sequence of a conserved neutralizing epitope of murine coronaviruses. J Virol 1989;63:1408 -12 .

18) Chouljenko VN, Kousoulas KG, Lin X, Storz J. Nucleotide and predicted amino acid sequences of all genes encoded by the $3^{\prime}$ genomic portion $(9.5 \mathrm{~kb})$ of respiratory bovine coronaviruses and comparisons among respiratory and enteric coronaviruses. Virus Genes 1998;17:33-42.

19) Zuo X, Xiao Y, Plaxco KW. High specificity, electrochemical sandwich assays based on single aptamer sequences and suitable for the direct detection of smallmolecule targets in blood and other complex matrices. J Am Chem Soc 2009;131:6944-5.

20) Lin XQ, KL Oe, Storz J, Purdy CW, Loan RW. Antibody responses to respiratory coronavirus infections of cattle during shipping fever pathogenesis. Arch Virol 2000;145:2335-49.

21) Yoo D, Deregt D. A single amino acid change within antigenic domain II of the spike protein of bovine coronavirus confers resistance to virus neutralization. Clin Diagn Lab Immunol 2001;8:297-302.

22) Abraham S, Kienzle TE, Lapps W, Brian DA. Deduced sequence of the bovine coronavirus spike protein and identification of the internal proteolytic cleavage site.
Virology 1990;176:296-301.

23) Boireau P, Cruciere C, Laporte J. Nucleotide sequence of the glycoprotein $\mathrm{S}$ gene of bovine enteric coronavirus and comparison with the $\mathrm{S}$ proteins of two mouse hepatitis virus strains. J Gen Virol 1990;71:487-92.

24) Storz J, Zhang XM, Rott R. Comparison of hemagglutinating, receptor-destroying, and acetylesterase activities of avirulent and virulent bovine coronavirus strains. Arch Virol 1992;125:193-204.

25) Zhang XM, Kousoulas KG, Storz J. Comparison of the nucleotide and deduced amino acid sequences of the $\mathrm{S}$ genes specified by virulent and avirulent strains of bovine coronaviruses. Virology 1991;183:397-404.

26) Rekik MR, Dea S. Comparative sequence analysis of a polymorphic region of the spike glycoprotein S1 subunit of enteric bovine coronavirus isolates. Arch Virol 1994;135:319-31.

27) Hasoksuz M, Sreevatsan S, Cho KO, Hoet AE, Saif LJ. Molecular analysis of the S1 subunit of the spike glycoprotein of respiratory and enteric bovine coronavirus isolates. Virus Res 2002;84:101-9.

28) Ko CK, Kang MI, Lim GK, Kim GY, Yoon SS, Park JT, Jeong C, Park SH, Park SJ, Kim YJ, Jeong JH, Kim SK, Park SI, Kim HH, Kim KY, Cho KO. Molecular characterization of HE, M, and E genes of winter dysentery bovine coronavirus circulated in Korea during 2002 2003. Virus Genes 2006;32:129-36.

29) Jeong JH, Kim GY, Yoon SS, Park SJ, Kim YJ, Sung CM, Shin SS, Lee BJ, Kang MI, Park NY, Koh HB, Cho KO. Molecular analysis of $\mathrm{S}$ gene of spike glycoprotein of winter dysentery bovine coronavirus circulated in Korea during 2002 2003. Virus Res 2005;108:207-12.

30) Park SJ, Jeong C, Yoon SS, Choy HE, Saif LJ, Park SH, Kim YJ, Jeong JH, Park SI, Kim HH, Lee BJ, Cho HS, Kim SK, Kang MI, Cho KO. Detection and characterization of bovine coronaviruses in fecal specimens of adult cattle with diarrhea during the warmer seasons. J Clin Microbiol 2006;44:3178-88.

31) Yang DK, Kweon CH, Kim BH, Park JK, So BJ, Song JY. Serological Survey of Bovine Coronavirus in Korea. J Bacteriol Virol 2007;37:105-9.

32) Han MG, Cheon DS, Zhang X, Saif LJ. Cross-protection against a human enteric coronavirus and a virulent 
bovine enteric coronavirus in gnotobiotic calves. J Virol 2006;80:12350-6.

33) Laude H, Talbot PJ, Levy GA. Corona related Virus: Functional Domains in the Spike Protein of Transmissible Gastroenteritis Virus. Plenum Press, New York 1995:299-394.
34) Park SJ, Lim GK, Park SI, Kim HH, Koh HB, Cho KO. Detection and molecular characterization of calf diarrhoea bovine coronaviruses circulating in South Korea during 2004 2005. Zoonoses Public Health 2007;54:223-30. 